\title{
Firms around the World during the COVID-19 Pandemic
}

\author{
Andreas Waldkirch ${ }^{1+}$ \\ ${ }^{1}$ Colby College, USA
}

\begin{abstract}
This study uses the COVID-19 follow-up surveys to the World Bank's Enterprise Surveys (ES) to analyze the impact of the COVID-19 pandemic on firms around the world. The surveyed countries are selected from those in which the regular ES was recently conducted. This study finds that the pandemic's impact has been swift, large, and heterogeneous. The pandemic's negative effects on exports are greater than those on domestic sales and are also greater for foreign-owned firms that rely more on global value chains. The pandemic's effects are very heterogeneous across countries and sectors.
\end{abstract}

Keywords: COVID-19, trade, multinationals, integration, firms

JEL Classifications: F14, F23, O57

Received 23 September 2020, Revised 27 January 2021, Accepted 8 February 2021

\section{Introduction}

The novel coronavirus (i.e., SARS-COV2) and the associated disease (i.e., COVID-19) have upended business as usual in countries around the world. Although the virus originated in Wuhan city in China's Hubei Province in December 2019, it quickly spread around the world, resulting in the largest pandemic in the modern globalized era. Nearly every government reacted with quarantine and lockdown measures. Many factories and businesses closed at least temporarily, disrupting countries' economies. As a result, trade in final and intermediate goods fell as global value chains were disrupted. ${ }^{1)}$ At the same time, contagion rates have been very heterogeneous across countries and across regions within countries. The number of new cases (seven-day rolling average per one million inhabitants) peaked in Spain at the end of March at 167.9, but many countries in Africa continue to report relatively few cases. ${ }^{2)}$ Moreover, the political reaction varies considerably across countries, even among countries with similar contagion rates and per capita cases.

This study provides evidence on the disruption created by the pandemic for a set of 21 countries in Europe, Latin America, Africa, and Asia for which the World Bank's Enterprise Analysis unit has conducted firm surveys asking specific questions about business during the 
COVID-19 pandemic. The surveys follow up on recently conducted regular Enterprise Surveys (ES), and thus allow comparisons to 'normal times', although some questions in the COVID-19 surveys were also asked retrospectively. These surveys could be conducted quickly because a representative sample with contact information was readily available for those countries. First, it was ascertained whether an establishment remained open or had permanently or temporarily shut down. For those open or temporarily shut-down, questions were asked about the pandemic's effects on a range of indicators. These include the impact on sales, purchases of inputs, employment, the firm's financial situation, online sales, and remote work, among others. The survey distinguished between national sales and export sales. These indicators are also included in the baseline regular surveys.

This study also investigates whether foreign-owned firms are faring differently from domestically owned firms. On the one hand, multinational companies may be better able to weather the storm, as they are more financially stable or have access to multiple sources of inputs, thereby minimizing disruptions to the supply chain. On the other hand, these firms may also be exposed to the pandemic's impacts on a larger scale, in multiple countries, and at different times given the differential timing of the virus's spread and mandated quarantines and shutdowns in different countries. Moreover, multinationals tend to produce goods whose demand is especially sensitive to economic conditions, and, thus may see a greater reduction in demand (Markusen, 2002, p. 13).

Using the data from the baseline and COVID-19 follow-up surveys from the ES, this study provides a snapshot of the disruption caused by the pandemic across countries. The first few waves of interviews were concluded by the middle of August 2020, and the data were made available shortly thereafter. Although more surveys are being implemented or are planned for the future, the data used in this study come from 21 countries in Europe (including Russia), Africa, Latin America, and Asia.

The analysis reveals that the pandemic has indeed had a large impact across countries. More than half of all firms close at least temporarily. Sales decrease for the vast majority of firms. Export sales decrease more than national sales and foreign-owned firms, which are more interconnected with the world economy, are disproportionately affected. At the same time, there is considerable heterogeneity across countries and sectors.

1) The World Trade Organization expects world merchandise trade to fall by 13 to 32 percent in 2020 owing to the pandemic. Preliminary figures indicate that trade fell by 18.5 percent in the second quarter of 2020 from the previous year but declined by a smaller percentage in the third quarter. However, with new quarantines and lockdowns following the second wave in late 2020 and early 2021, no recovery is expected soon (wto.org).

2) These numbers, in both absolute and comparative terms, should be looked at with extreme caution. The availability of testing and the compilation of daily statistics varies widely across countries. Moreover, the impact on the economy and the prevalence of lockdowns or shutdowns may be more of a function of rising cases in other countries, as a country may shutter its economy as a preventative measure rather than as a reaction to a high number of cases detected domestically. For the source of these data, see the dashboard at ft.com/covid19. 
The next section provides more details about the ES, and Section 3 describes the results of the analysis. Section 4 concludes.

\section{Data}

The data were collected by the World Bank's ES unit. The World Bank has conducted surveys of individual establishments annually since 2002 and adds new data every year. Some of the surveys are focused on specific issues, such as the effects of the 2008-2009 financial crisis or micro-enterprises. Most, however, are designed to have representative samples that are stratified across industry, region and establishment size. The questionnaires that these surveys use have been standardized since at least 2005, which make the data comparable across countries.

From the beginning, the main purpose of the surveys was to gain a better understanding of the operations of firms in developing countries, especially the very poorest ones, and the obstacles that they are facing. For many countries, this information was simply unknown because no survey or census data were available. Many of the questions therefore ask about problems encountered in the operations of the business. These include limited or interrupted access to electricity, water, and telecommunications. The survey also asks about the (un-)availability of credit and relationships with government agencies and officials, such as whether a bribe must be paid to obtain certain licenses and the time it takes to export goods.

The questionnaires also ask about establishment characteristics that are useful for investigating other questions. These include the value of sales, employment, and export status, among others. It is also known whether an establishment is domestically or foreign-owned, although it does not provide information on the nationality of the foreign owner(s).3)

Special COVID-19 follow-up surveys to date (end of August 2020) have been conducted and data collected for 21 countries in Europe, including former Soviet Republics and Russia; Latin America; Africa; and Asia. ${ }^{4}$ ) Owing to resource limitations, the surveys were not administered at the same time in every country. The earliest survey (in Moldova) was concluded by the end of May, whereas the other surveys were concluded as late as August, with Mongolia's survey conducted entirely in August. Some questions refer to "the last full month before the survey", e.g., for sales, and compare to the same month in the previous year. Thus, although sales changes may be as early as April 2020 compared to April 2019 and as late as July

3) See the ES website (enterprisesurveys.org) for more information. The data are available for download to registered researchers.

4) The countries are Albania, Armenia, Chad, Cyprus, El Salvador, Georgia, Greece, Guatemala, Guinea, Honduras, Italy, Jordan, Moldova, Mongolia, Nicaragua, Niger, Russia, Slovenia, Togo, Zambia, and Zimbabwe. See Appendix Table A1 for the dates that the surveys were administered in each country and the number of domestic and foreign establishments surveyed. 
2020 relative to July 2019, seasonal effects should not distort the results. It is of course also true that countries are at different stages of the pandemic at different times. These differences are roughly reflected in the timing of the surveys, with European countries being surveyed earlier and countries whose cases started rising later, such as Mongolia, being surveyed later. Table A1 shows the prevalence of COVID-19 cases on the day before the survey started and on the last day of the survey for each country. As discussed in footnote 1, however, one should not read too much into the differences in prevalence of cases at that point. Given the pandemic's spread and severity, which had become clear by March 2020,5) many countries took preventative measures affecting the economy even in the absence of a heavy domestic caseload in order to preclude the kind of large-scale issues facing countries hit hard early, such as Italy and Spain. This explanation may especially hold for countries with weak health systems, which is the case for several countries in the sample, who feared getting overwhelmed with patients in hospitals quickly and, thus, took drastic measures early on.

\section{Data Analysis}

This section documents the findings from the COVID-19 follow-up surveys, in some cases comparing the data to equivalent data from the last regular, pre-COVID-19 survey. Particular attention is paid to the effect on involvement with the world economy, such as those via exports, and effects on multinational versus domestic firms.

Before discussing the data on changes in the international integration of firms as a result of the pandemic, we first discuss some basic information on the impacts to businesses in the 21 countries analyzed in this study.6) Of the businesses that respond, 4.1 percent had closed permanently, and 11.8 percent are closed temporarily. However, of the businesses that remained open, 53.9 percent were temporarily closed at some point due to COVID-19, with a median closure time of six weeks. Figure 1a shows the distribution across industries. ${ }^{7)}$ Industries are defined according to the United Nation's two-digit International Standard Industrial Classification system (ISIC Revision 3.1). After dropping sectors with fewer than ten firms, we have 25 sectors, 18 in manufacturing and seven are services sectors. ${ }^{8)}$ One-third of hotels and restaurants are currently closed, and over 30 percent of those that are open were closed for at least some time.

5) The World Health Organization declared a global pandemic on March 11, 2020.

6) The establishments that are surveyed may be part of a larger firm, but they often are not. Over 80 percent of establishments report that they are not part of a larger firm. In the text, the terms "firm," "establishment," and "business" are used interchangeably.

7) Appendix Table A2 lists the industries and provides summary statistics, such as the number of domestic and foreign establishments, by sector.

8) The excluded sectors are tobacco and refined petroleum products. 
Closure rates are highest in labor-intensive manufacturing such as garments, leather, and furniture, and lower in more skill- or capital-intensive manufacturing such as chemicals and machinery. Nevertheless, these data understate the true scope of affected firms, as a significant number of firms could no longer be contacted. While it cannot be determined whether the firms that could no longer be reached went out of business (and whether owing to the pandemic, or before) or simply moved without providing new contact information. However, it is worth noting that of 9,385 establishments that were in the last pre-COVID-19 survey, 6,091 or 64.9 percent responded and are currently open. A better measure may be to count those firms that were successfully contacted, 7,922 or 84.4 percent, a percentage close to those that answered the survey and are open. ${ }^{9)}$

The majority of businesses in the surveyed countries are small, with median employment of 19 prior to COVID-19.10) Some studies provide evidence on the incidence of small business closures as a result of the early quarantine orders and lockdowns. Using data from the United States' Current Population Survey (CPS), Fairlie (2020) finds that during the first three months of the pandemic, the number of active small business owners fell by 22 percent. In the ES data, businesses that are temporarily or permanently closed had just under 40 full-time employees on average prior to the pandemic (median: 11), whereas those that remain open had 91 full-time employees on average (median: 20), indicating that small businesses are significantly more likely to close than larger ones. Figure $1 \mathrm{~b}$ shows the distribution of median employment across sectors for closed and open establishments. Except in the basic metals and recycling sectors, the closed businesses are smaller, often by a considerable margin.

Layoffs in firms still in business (permanently closed firms were not asked further questions) are limited. The average share of full-time workers employed at the end of the last month before the survey relative to the number of full-time workers at the end of 2019 is 0.91. 26.7 percent of firms report nonzero layoffs. In those firms, the median number of workers laid off is five. However, these numbers become more substantial when furloughed workers are considered as well. Nearly half of all firms furloughed someone, with a median of eight workers. In addition, there are a substantial number of firms that have furloughed more than 50 people, 12.5 percent, so that the average number of furloughed workers is nearly 30 . The median number of workers in these firms is 17 (average: 63). Thus, the workforce reduction, including both laid-off and furloughed workers, has been rather large but partly temporary. Figure 2 shows the distribution of the median shares of both layoffs and furloughs across industries for firms with nonzero numbers of each. In all sectors except wood, the fraction of furloughed workers exceeds the fraction of laid-off workers. The three highest shares are in hotels and restaurants, furniture, and printing.

9) Of the successful contacts, 606, or 7.6 percent, refused to answer the follow-up survey.

10) Appendix Table A2 provides means and standard deviations. There is considerable skewness in the data owing to a few large firms, and, thus, the means tend to be much higher than the medians. 
Figure 1a. Share of establishments that are currently closed and share of open establishments that closed temporarily

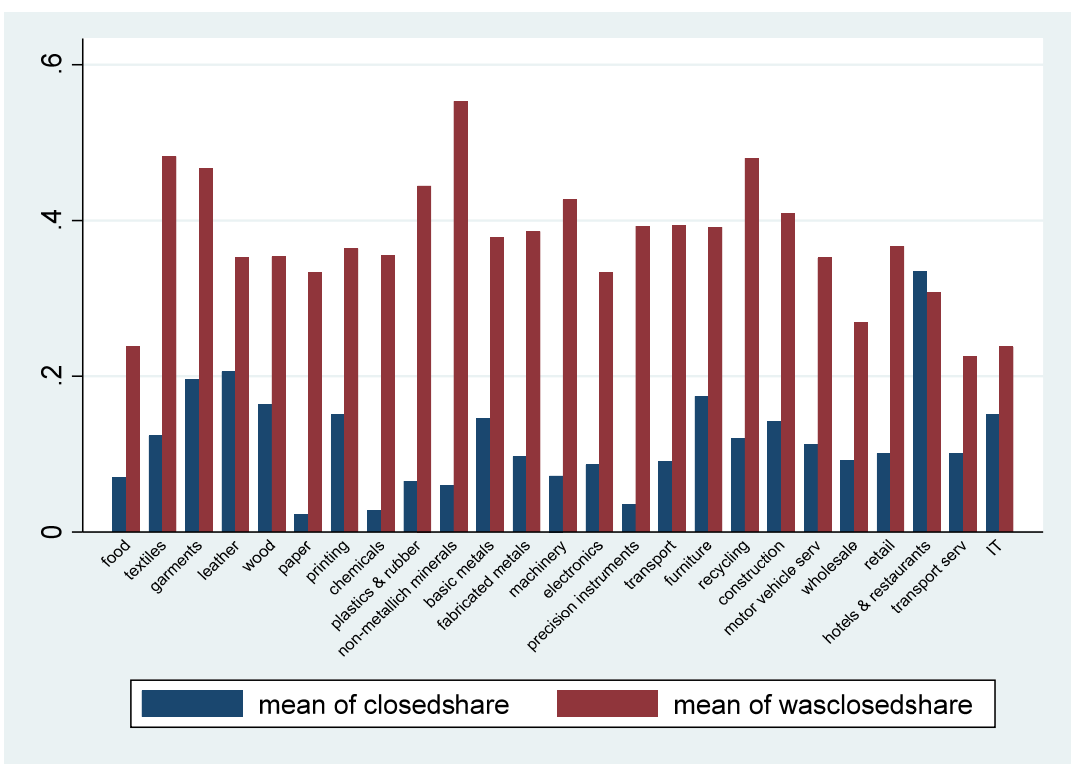

Notes. For each sector, the left bar shows the share of establishments that are closed (temporarily or permanently) at the time of the COVID-19 follow-up survey. The right bar shows the share of currently open establishments that temporarily closed at some point since the start of the pandemic.

Figure 1b. Median pre-COVID-19 employment of currently closed and currently open establishments

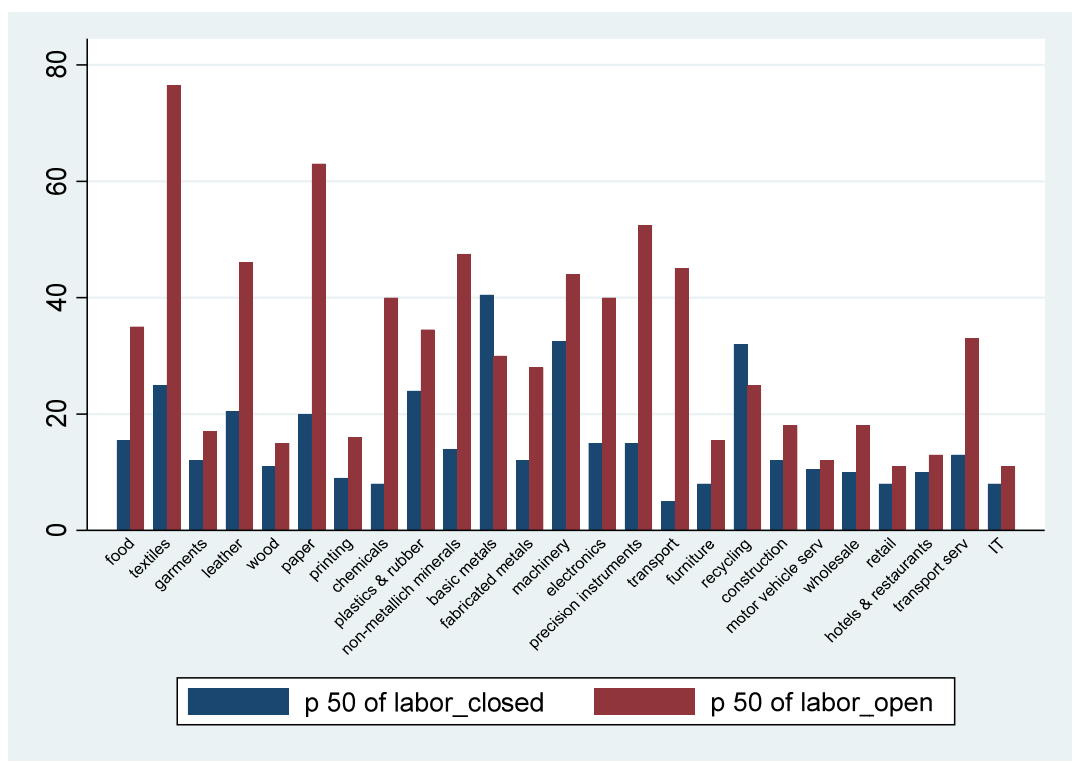

Notes. For each sector, the left bar shows the median employment of establishments that are closed (temporarily or permanently) at the time of the COVID-19 follow-up survey. The right bar shows the median employment of establishments that are currently open. 
Layoffs in firms still in business (permanently closed firms were not asked further questions) are limited. The average share of full-time workers employed at the end of the last month before the survey relative to the number of full-time workers at the end of 2019 is 0.91 .26 .7 percent of firms report nonzero layoffs. In those firms, the median number of workers laid off is five. However, these numbers become more substantial when furloughed workers are considered as well. Nearly half of all firms furloughed someone, with a median of eight workers. In addition, there are a substantial number of firms that have furloughed more than 50 people, 12.5 percent, so that the average number of furloughed workers is nearly 30 . The median number of workers in these firms is 17 (average: 63). Thus, the workforce reduction, including both laid-off and furloughed workers, has been rather large but partly temporary. Figure 2 shows the distribution of the median shares of both layoffs and furloughs across industries for firms with nonzero numbers of each. In all sectors except wood, the fraction of furloughed workers exceeds the fraction of laid-off workers. The three highest shares are in hotels and restaurants, furniture, and printing.

Figure 2. Layoffs and furloughs, fraction by industry

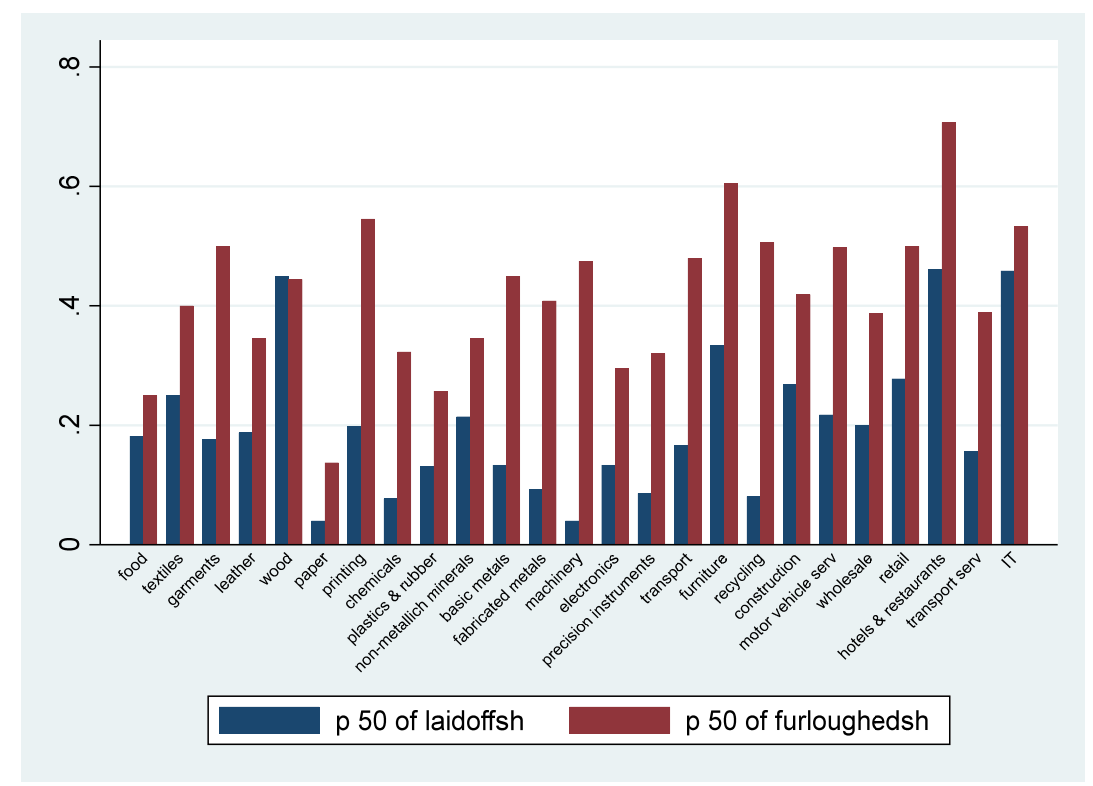

Notes. For each sector, the left bar shows the median fraction of laid-off workers, and the right bar shows the median fraction of furloughed workers, conditional on layoffs and furloughs, respectively, being nonzero.

There are several other interesting reactions to the pandemic, documented in Table 1a, separately for all firms and foreign firms only. ${ }^{11)} 30.2$ percent of businesses start or increase

11) In accordance with common international standards, e.g., those of the International Monetary Fund (IMF), 
business activity online, although the share of online sales is zero for more than two-thirds of all firms. 28.5 percent of firms start or increase delivery or carry-out of goods and services, with similar numbers for foreign firms. Even more firms start or increase remote work arrangements for their workforce, with 35.7 percent of all businesses and 47.5 percent of foreign-owned businesses reporting having done so. On average, 25.9 percent of workers in those are working remotely, with 30.9 percent of workers in foreign-owned firms working remotely.

Table 1a. Online, Delivery, and Carry-out Sales and Remote Work

\begin{tabular}{lcc}
\hline & All firms & Foreign firms \\
\hline Business activity online started or increased & 30.2 & 27.9 \\
Share of online sales = zero & 67.4 & 68.3 \\
Delivery or carry-out of goods and services started or increased & 28.5 & 26.3 \\
Remote work arrangements started or increased & 35.7 & 47.5 \\
Share of workers working remotely / remote work is offered & 25.9 & 30.9 \\
\hline
\end{tabular}

Notes. Rows 1, 3, and 4 show the shares of firms that answered the listed questions in the affirmative. Row 2 shows the share of establishments that reported no online sales. Row 5 reports the mean share of workers working remotely only in firms that offer that option.

Table 1b. Changes in Sales, Demand, Hours Worked, Supply of Intermediate Inputs, and Capacity Utilization, all Firms and Foreign Firms

\begin{tabular}{|c|c|c|c|}
\hline & Decline & Stay the same & Increase \\
\hline Sales, all firms & 80.2 & 13.1 & 6.7 \\
\hline Sales, foreign firms & 79.3 & 13.3 & 7.3 \\
\hline Capacity utilization, all firms & 64.0 & 14.9 & 21.1 \\
\hline Capacity utilization, foreign firms & 61.3 & 17.2 & 21.5 \\
\hline Hours worked, all firms & 63.0 & 33.8 & 3.2 \\
\hline Hours worked, foreign firms & 64.7 & 32.8 & 2.5 \\
\hline Supply of inputs, all firms & 68.5 & 24.5 & 7.1 \\
\hline Supply of inputs, foreign firms & 65.9 & 26.4 & 7.7 \\
\hline
\end{tabular}

Notes. All numbers are the percentages of all respondents that reported a decline, no change, or an increase in the listed characteristic. All rows sum to 100.

These disparities in remote work are consistent with evidence found elsewhere. Bartik et al. (2020) find that about 60 percent of employees of large businesses in the United States are able to telecommute, but only 27 to 31 percent of employees in a sample that focuses on small businesses are. When size is measured by employment, there is indeed a statistically significant, albeit small (0.09), correlation between firm size and whether anyone is working remotely in the ES sample. Alfaro et al. (2020) focus on the immediate and later responses to the pandemic and the initial closures and lockdowns in emerging economies. These economies 
are characterized by small firms and informality. Applying data from Colombia to their framework, they find that well over 50 percent of jobs are at risk in the initial stages of the crisis, as many are not suited to remote work and rely on close contact with their customers. This explanation similarly holds in the much larger ES sample for the smaller domestic and less so for the larger foreign firms.

Table $1 \mathrm{~b}$ documents the share of respondents that see a decline, no change, or increase in sales, capacity utilization, hours worked, and input supplies, again separately for all firms and foreign firms only. Just over 80 percent of firms see their sales decline in the full month prior to the survey compared to the same month in the previous year. Only 6.7 percent see a sales increase. For those that experience a decrease in sales, it is substantial, with a median as well as a mean decrease of about 50 percent. For those businesses that remain open, there are several ways they adjust to falling sales. Capacity utilization falls for 64 percent of all firms. The mean (median) capacity utilization drops from 74.7 (80) to 56.3 (60) percent. Total hours worked per week decrease for 63 percent of all establishments. The corresponding number for foreign-owned firms is slightly higher, almost 65 percent. Overall, sales fall by the most, whereas capacity utilization and hours worked adjust by smaller margins. It is also worth noting that input supplies fall for the majority of firms as well. For all measures, there are scant differences between foreign and domestic firms.

An important measure of a firm's involvement in the global economy is through exporting. The data divide sales into those that are destined for the domestic market and those that are exports (directly or indirectly). For all firms in the sample, regardless of ownership status, the average share of export sales was 11.5 percent before COVID-19. This share falls to 10.2 percent with COVID-19 present. 80.2 percent of firms report that total sales fell compared to the same month in the previous year. Thus, because overall sales fall, the decrease in exports must have been greater than the decline in domestic sales. However, only 55 percent of firms that export at all report a decrease in export sales. It follows that for many exporting firms, the fall in export sales must have been very large, larger than the typical drop in sales to the domestic market. ${ }^{12}$ ) This demonstrates that although the pandemic has had a mostly negative effect on overall sales, its effect on exports has been even more pronounced.

Direct and supply chain trade have both been severely impacted by the crisis (Sforza \& Steininger, 2020). However, as Figure 3a demonstrates, this general result hides a good degree of heterogeneity. Although most countries are below the 45-degree line, in accordance with their share of export sales falling as a result of COVID-19, there are a number of countries with increasing export sales shares, notably Chad and Niger in Africa, as well as Jordan and Italy, which was the first Western European country to be hit hard by the pandemic. For Italy,

12) Unfortunately, the COVID-19 survey asks only about shares rather than about sales volumes, as in the regular surveys, so this conclusion has to be drawn indirectly. 
12 Journal of Economic Integration Vol. 36, No. 1

Figure 3a. Export shares of sales pre- and post-COVID-19

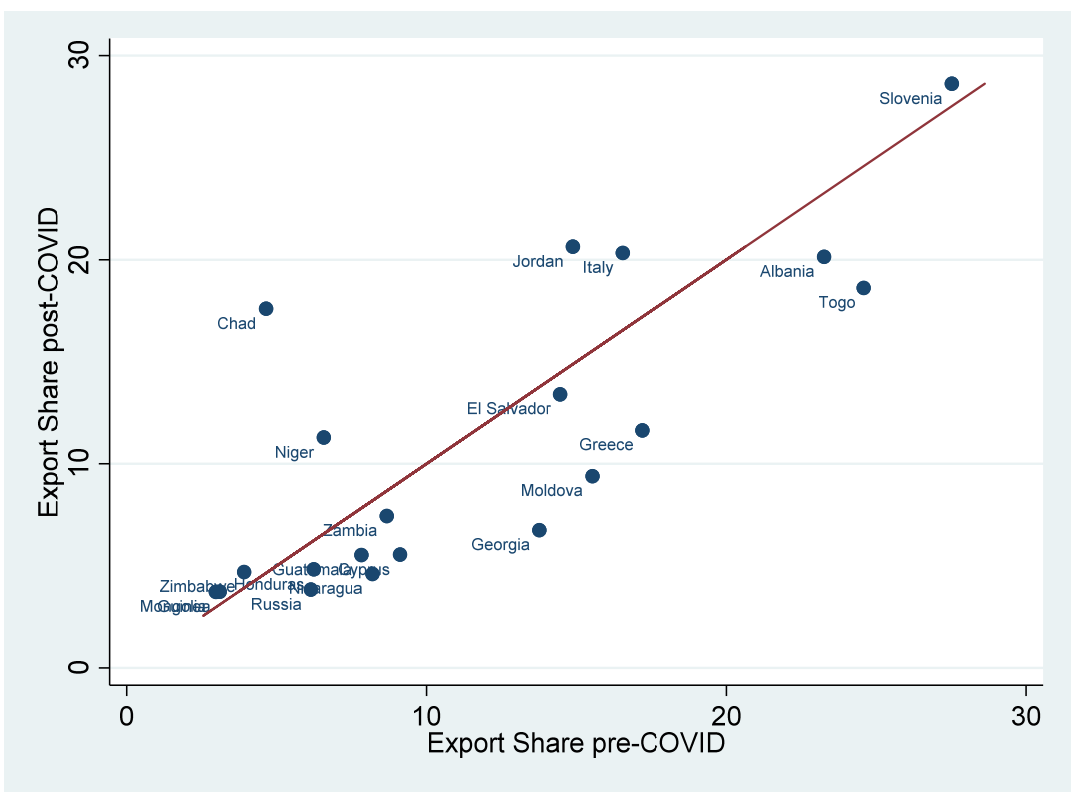

Notes. Shown is the 45-degree line. If a country is below the 45-degree line, the pre-COVID-19 export share of sales exceeds that during COVID-19. The opposite holds for countries above the 45-degree line.

Figure 3b. Export shares of sales pre- and post-COVID-19 for foreign-owned firms.

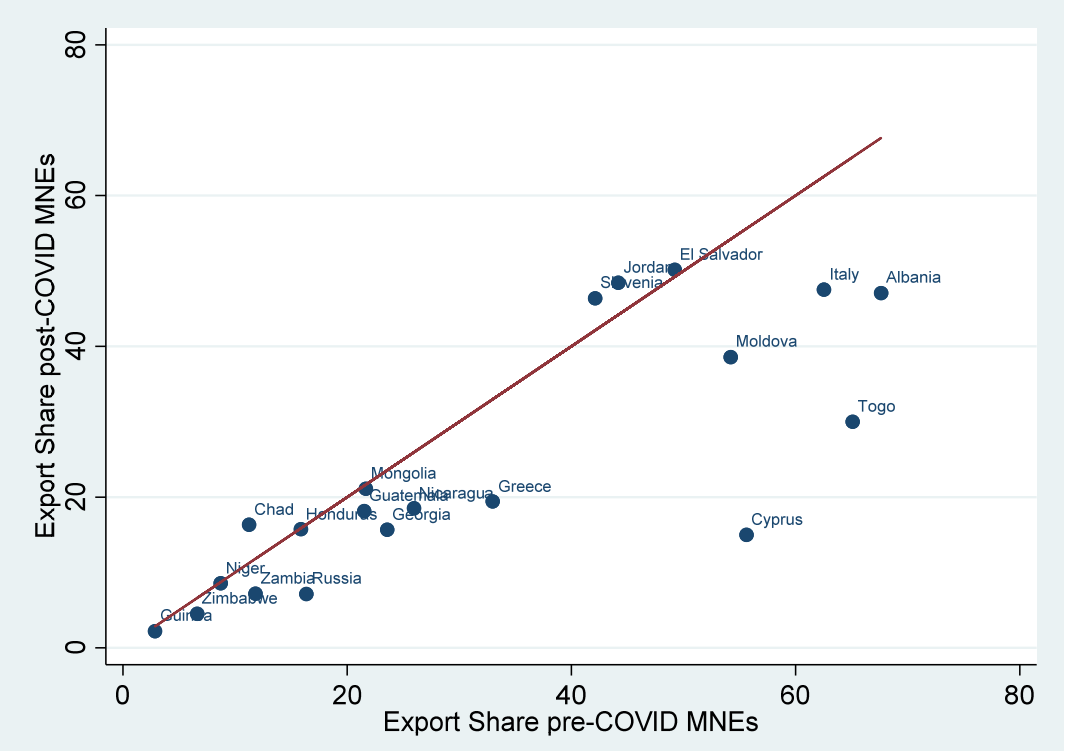

Notes. Shown is the 45-degree line. If a country is below the 45-degree line, the pre-COVID-19 export share of sales exceeds that during COVID-19. The opposite holds for countries above the 45-degree line. 
the explanation is that export sales only decline for 38 percent of responding firms, whereas overall sales decline for 73.5 percent. Thus, even if some exports fall by more than domestic sales, as must have been the case for all countries combined, this apparently is not the case for Italy or the other countries above the 45-degree line.

The picture is even more dramatic when we look only at multinationals, identified in the data as those firms that are foreign-owned.13) For these firms, exports were 26.7 percent of sales before COVID-19, which unsurprisingly is far higher than the export share for all firms as multinationals are known to have a greater involvement in the world economy than domestic firms (Antràs \& Yeaple, 2014). This share falls dramatically to 20.4 percent during the COVID-19 pandemic (an almost 25 percent decline), with a similar share of firms reporting a decrease in sales as all firms (79.3 versus 80.2 percent). 56.5 percent of foreign-owned firms report a decrease in export sales. Figure $3 \mathrm{~b}$ shows the changes in export shares for multinationals by country. Most countries are below the 45-degree line, indicating a fall in the export share post-COVID-19, in some cases to a dramatic extent. Only a handful of countries are above the 45-degree line, and then only by a small amount. Most notably, two of the countries whose firms experience an overall increase in the export share, Togo and Italy, experience a large decrease for multinationals. This result shows that global supply chains must have been severely impacted for multinationals operating in Italy but that exports remain far more stable for all Italian firms.

Why does the export share fall more dramatically for multinationals? The likeliest explanation is that domestic firms largely export final goods to consumers in foreign markets, whereas multinationals are involved in global supply chains with substantial trade in intermediates. These global supply chains were more severely disrupted by the pandemic than traded goods reaching final consumers were (Meier \& Pinto, 2020; Sforza \& Steininger, 2020). The ES data provide some evidence supporting this conjecture. Whereas domestic firms source 36.7 percent of their inputs from foreign sources, the corresponding share for foreign-owned firms is 54.3 percent.

We can also look at the heterogeneity of exports and changes in the export share across sectors. Except for transport services, services sectors tend to have lower shares of sales going to exports than manufacturing sectors have, as Figure 4a shows. Among those, textiles, leather, and electronics all have export shares greater than 30 percent prior to the COVID-19 pandemic. Almost all manufacturing sectors see a declining sales share of exports. For services, however, this share only declined for the hotel and restaurant category, where tourism, which has suffered tremendously from the pandemic, accounts for exports. The decline in the export shares among manufacturing sectors is dramatic in a few sectors, such as leather and electronics. For the latter, complex global value chains are important and again, these appear to have suffered the greatest disruption. Figure $4 \mathrm{~b}$ shows similar trends for foreign-owned firms (some additional

13) We cannot identify domestic multinationals (i.e., domestically owned firms that may have foreign affiliates) in the data. 
Figure 4a. Export shares before and during the COVID-19 pandemic, cross-country means, by sector

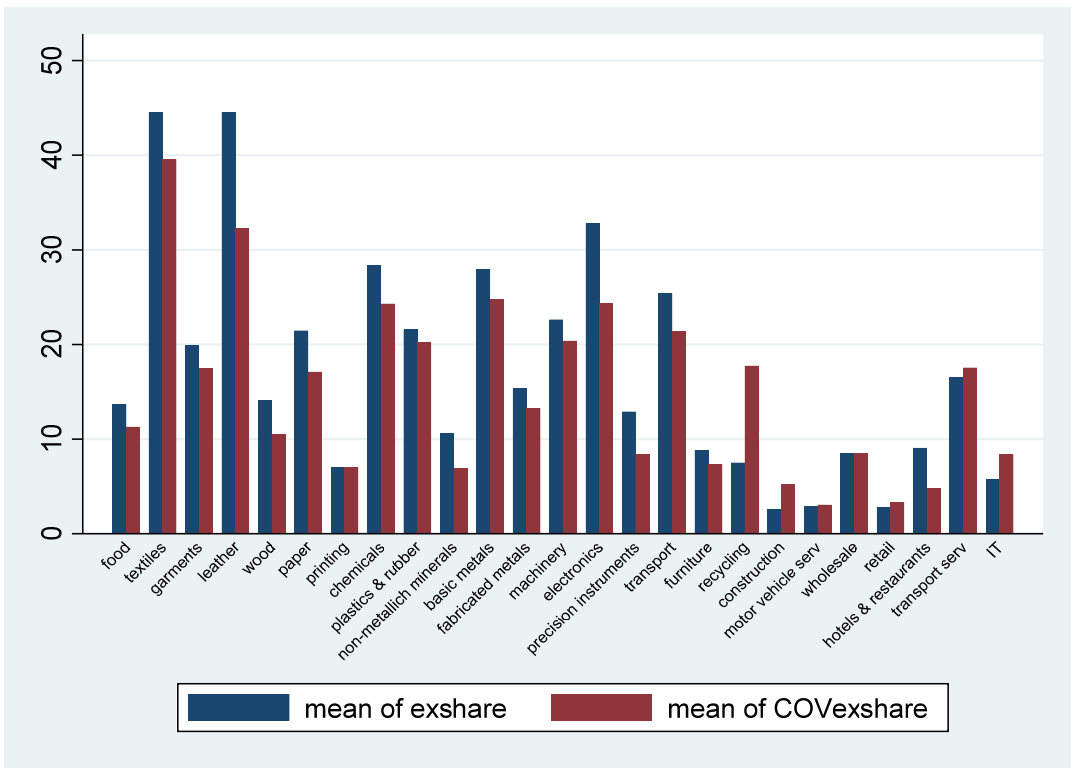

Notes. Sectors with fewer than ten firms are omitted. For each sector, the left bar shows the export share of sales before COVID-19. The right bar shows the export share of sales during the COVID-19 pandemic.

Figure 4b. Export shares before and during the COVID-19 pandemic for foreign-owned firms, by sector

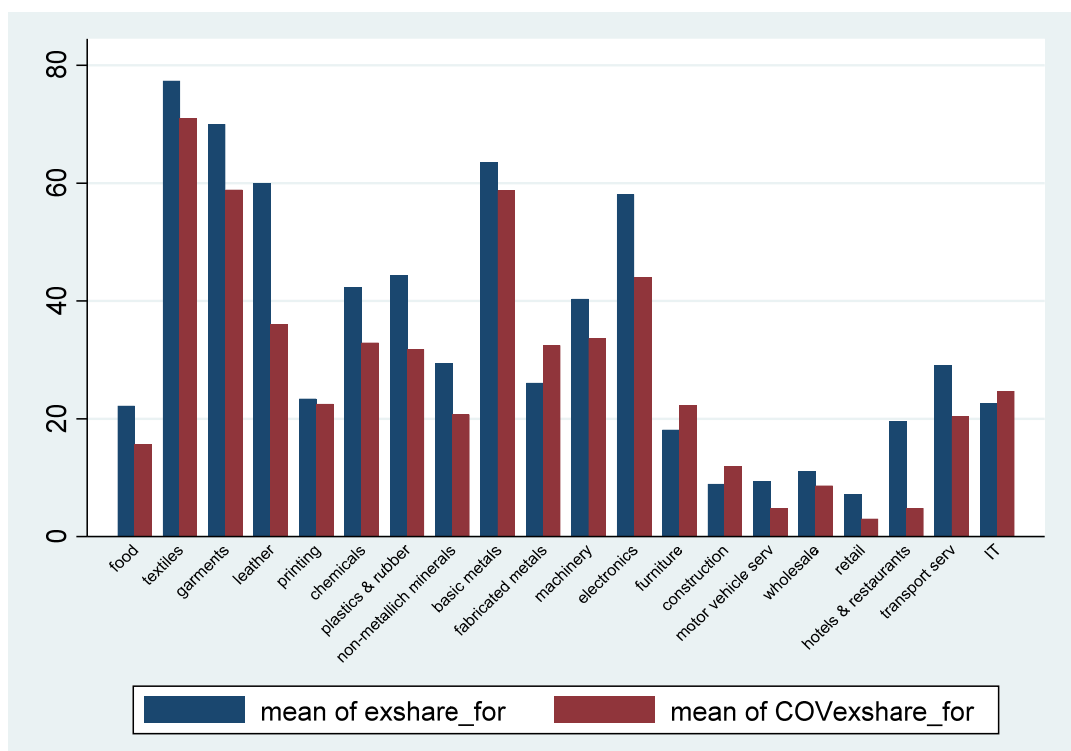

Notes. Sectors with fewer than ten firms are omitted. For each sector, the left bar shows the export share of sales before COVID-19. The right bar shows the export share of sales during the COVID-19 pandemic. 
sectors with fewer than ten foreign-owned firms are omitted), ${ }^{14)}$ but, as before, these firms have considerably higher export shares of their sales than all firms have.

To be more formal, we regress the change in the export share of sales (COVIDshare less pre-COVIDshare) on establishment size, measured as full-time employment, indicator variables for whether a firm is foreign-owned and whether it is in manufacturing and the share of inputs that are sourced from abroad. All of these variables are indicators that a firm is more likely to be involved internationally via exporting. As shown in Table 2, the coefficients on these variables are all statistically significant with negative signs. This implies that the drops in the shares of export sales are bigger for larger, foreign-owned, and manufacturing firms as well as those with a higher share of inputs sourced from abroad, confirming that firms with these characteristics are hit harder by the decrease in international trade resulting from the pandemic. Specifically, using the preferred specification (4), which includes country and sector fixed effects, a foreign-owned firm experiences a 6.5 percentage point greater decrease in the share of export sales than a domestic firm does, all else equal. A manufacturing firm's decrease in exports is 17 percentage points greater than that of a services firm. A ten percentage point greater reliance on imported intermediates is associated with a 1.2 percent greater decrease in exports. All of these results are statistically significant regardless of whether country and/or sector fixed effects are included, although the exact magnitudes differ.

Table 2. Changes in the Export Share as a Function of Firm Characteristics

\begin{tabular}{lcccc}
\hline & $(1)$ & $(2)$ & $(3)$ & $(4)$ \\
\hline Establishment size & $-0.002^{*}(0.001)$ & $-0.002(0.001)$ & $-0.003 * *(0.001)$ & $-0.002 *(0.001)$ \\
Foreign-owned & $-7.956^{* * *}(2.272)$ & $-6.805^{* * *}(2.352)$ & $-6.834 * *(2.262)$ & $-6.548^{* * *}(2.313)$ \\
Manufacturing & $-5.799^{* * *}(1.973)$ & $-6.507 * * *(1.964)$ & $-17.804 * * *(6.455)$ & $-17.097 * * *(6.546)$ \\
Imported Intermediates & $-0.097 * * *(0.024)$ & $-0.106^{* * *}(0.025)$ & $-0.133 * * *(0.025)$ & $-0.123^{* * *}(0.027)$ \\
Country FE? & No & Yes & No & Yes \\
Sector FE? & No & No & Yes & Yes \\
R-squared & 0.022 & 0.104 & 0.053 & 0.131 \\
\hline
\end{tabular}

Notes. This table shows the results of regressing the change in the share of export sales pre-COVID-19 to after the emergence of COVID-19 on establishment size (i.e., the number of workers), an indicator of whether an establishment is foreign-owned, whether it is in manufacturing and the share of imported intermediate goods. Robust standard errors are shown in parentheses. All regressions have 2,111 observations. Column (1) includes only the indicated variables. Column (2) additionally includes country fixed effects (FE), column (3) also includes sector FE, and column (4) includes both sets of FE. * indicates p-value $<0.1$, ${ }^{* *}$ indicates p-value $<0.05$, and $* * *$ indicates p-value $<0.01$.

14) The additional excluded sectors are wood, paper, precision instruments, transport machines, and recycling. 


\section{Conclusion}

Businesses across the world have been impacted by the COVID-19 pandemic. This study provides evidence from surveys that were entirely conducted during the pandemic in 21 countries across the world to gauge some of the pandemic's effects. The countries are mostly developing and transition economies plus Italy, Greece, and Cyprus. Notably, the surveys not only include some retrospective questions comparing businesses during with just before the pandemic but since they are based on representative samples of firms that were surveyed fairly recently before the pandemic, a direct comparison to those times is sometimes possible rather than having to rely on retrospective recall of respondents. The results show that many businesses had to close, most temporarily, some permanently, especially in hard-hit sectors, such as hotels and restaurants. Although some businesses have shifted more to online sales and remote work, the majority have not, as many jobs are not well suited to remote work in the mostly small businesses that comprise the sample and are typical for most of the surveyed countries.

The analysis of the international involvement of these firms reveals that exports have suffered more than domestic sales. The share of sales that are exports has fallen for all firms but has fallen much more for multinationals, which have a far higher export sales share than domestically owned firms. The impact has also been greater for big firms, firms in manufacturing rather than services, and firms that rely more heavily on imported inputs. The analysis also reveals significant heterogeneity both across countries and sectors. Some countries seem to have benefited from the global decline in exports and have expanded their export shares, although the majority of firms in most countries report decreasing exports. In the countries with increased export shares, domestic rather than foreign-owned firms are the beneficiaries. Among sectors, certain services, such as hotels and restaurants, and labor-intensive industries, such as garments, leather, and electronics, have been more heavily impacted than capital-intensive industries, such as chemicals and machinery.

Clearly, as this global pandemic is ongoing, there will be further impacts on firms around the world and the global trading system and global value chains. However, it is illuminating to observe the drastic immediate impact of the crisis on a worldwide basis.

\section{References}

Alfaro, L., Becerra, O., \& Eslava, M. (2020). EMEs and COVID-19: Shutting down in a world of informal and tiny firms (National Bureau of Economic Research Working Paper, No. 27360). National Bureau of Economic Research.

Antràs, P., \& Yeaple, S. R. (2014). Multinational firms and the structure of international trade. In G. 
Gopinath, E. Helpman, \& K. Rogoff (Eds.), Handbook of International Economics (Vol. 4; pp. 55-130). Amsterdam, The Netherlands: North Holland.

Bartik, A. W., Cullen, Z. B., Glaeser, E. L., Luca, M., \& Stanton, C. T. (2020). What jobs are being done at home during the COVID-19 crisis? Evidence from firm-level surveys. (National Bureau of Economic Analysis Working Paper, No. 27422).

Fairlie, R. W. (2020). The impact of COVID-19 on small business owners: The first three months after social-distancing restrictions. (National Bureau of Economic Analysis Working Paper, No. 27462). Markusen, J. R. (2002). Multinational firms and the theory of international trade. Cambridge, MA: The MIT Press.

Meier, M., \& Pinto, E. (2020). COVID-19 supply chain disruptions. Covid Economics, 48, 139-170.

Sforza, A., \& Steininger, M. (2020). Globalization in the time of COVID-19. Covid Economics, 19, 159-210. 
18 Journal of Economic Integration Vol. 36, No. 1

Table A1. Sample Countries and Survey Periods (all in 2020)

\begin{tabular}{|c|c|c|}
\hline Country & Survey Period & COVID prevalence \\
\hline Albania (342 dom, 35 for) & June $5-26$ & $5.7 / 22$ \\
\hline Armenia (120) & June 9-19 & $172.9 / 173.9$ \\
\hline Chad $(131,22)$ & June $18-28$ & $<0.1 /<0.1$ \\
\hline Cyprus $(347,13)$ & June 3-29 & $3.1 / 1.3$ \\
\hline El Salvador $(622,97)$ & June 10-August 6 & $12.6 / 64.5$ \\
\hline Georgia $(513,68)$ & June $2-10$ & $2.6 / 1.2$ \\
\hline Greece $(536,64)$ & June3-July 1 & $0.5 / 1.8$ \\
\hline Guatemala $(297,48)$ & June 24-August 7 & $30.7 / 44.8$ \\
\hline Guinea $(132,18)$ & June $16-27$ & $4.3 / 4$ \\
\hline Honduras $(294,38)$ & June 25-August 6 & $67.8 / 58.1$ \\
\hline Italy $(723,37)$ & May 27-June 26 & $8.9 / 4.4$ \\
\hline Jordan $(564,37)$ & July 5-August 12 & $0.6 / 1.2$ \\
\hline Moldova $(322,38)$ & May 19-29 & $62 / 57.7$ \\
\hline Mongolia $(345,15)$ & August 3-15 & $0.2 / 0.2$ \\
\hline Nicaragua $(272,61)$ & June 17-August 6 & $7.8 / 5$ \\
\hline Niger $(137,14)$ & June $17-27$ & $0.3 / 0.2$ \\
\hline Russia $(1269,54)$ & June 3-29 & $61 / 47.6$ \\
\hline Slovenia $(341,68)$ & July 6-August 5 & $9 / 5.7$ \\
\hline Togo $(99,51)$ & June $16-27$ & $0.6 / 1.3$ \\
\hline Zambia $(423,178)$ & June 16-July 14 & $1.6 / 3.1$ \\
\hline Zimbabwe $(484,116)$ & June 12-July 13 & $0.8 / 2.4$ \\
\hline
\end{tabular}

Notes. The numbers in parentheses after each country name represent the number of domestic and foreign establishments surveyed, respectively.

The COVID-19 prevalence shows the seven-day rolling averages of new cases per one million inhabitants on the day before the start of the survey / on the last day of the survey, respectively. Source: The Financial Times Dashboard (ft.com/covid19). See there for data sources for various countries. 
Table A2. Domestic and Foreign Firms, Employment, and Input Importer Status by Industry

\begin{tabular}{|c|c|c|}
\hline Industry & Employment & Input Importer \\
\hline Food (1061 dom, 143 for) & $128(506)$ & $22.4(30.3)$ \\
\hline Textiles $(126,44)$ & $160(293)$ & $59.4(39.9)$ \\
\hline Garments $(411,64)$ & $142(394)$ & $46.6(36.8)$ \\
\hline Leather $(57,11)$ & 108 (197) & $43.4(39.8)$ \\
\hline Wood (107) & $42(93)$ & $30.0(36.6)$ \\
\hline Paper (36) & $102(133)$ & $52.1(39.4)$ \\
\hline Printing $(188,18)$ & $35(81)$ & $50.3(42.6)$ \\
\hline Chemicals $(146,37)$ & $106(152)$ & $49.4(35.4)$ \\
\hline Plastics \& rubber $(128,25)$ & $92(148)$ & $61.2(37.5)$ \\
\hline Non-metallic minerals $(244,38)$ & $130(282)$ & $24.4(32.8)$ \\
\hline Basic metals $(67,15)$ & $318(2203)$ & $40.1(40.5)$ \\
\hline Fabricated metals $(464,31)$ & $88(205)$ & $30.2(33.4)$ \\
\hline Machinery $(325,36)$ & $163(631)$ & $37.4(32.8)$ \\
\hline Electronics $(66,15)$ & $127(367)$ & $51.5(33.7)$ \\
\hline Precision Instruments (26) & $113(192)$ & $31.5(30.2)$ \\
\hline Transport (30) & $330(1171)$ & $34.0(33.6)$ \\
\hline Furniture $(244,14)$ & $33(57)$ & $36.5(37.7)$ \\
\hline Recycling (24) & $80(147)$ & $11.4(22.3)$ \\
\hline Construction $(656,44)$ & $50(151)$ & $29.0(32.1)$ \\
\hline Motor vehicle services $(313,45)$ & $35(79)$ & $55.0(42.2)$ \\
\hline Wholesale trade $(819,115)$ & $55(123)$ & $50.6(41.5)$ \\
\hline Retail trade $(1691,178)$ & $47(274)$ & $49.1(40.1)$ \\
\hline Hotels and restaurants $(581,76)$ & 79 (1174) & $18.4(27.3)$ \\
\hline Transport services $(254,43)$ & $76(192)$ & $33.5(41.6)$ \\
\hline Information technology $(163,22)$ & $35(71)$ & $43.0(42.1)$ \\
\hline
\end{tabular}

Notes. The numbers in parentheses after each industry name represent the numbers of domestic and foreign establishments surveyed, respectively. Industries with only one number given have fewer than ten surveyed foreign-owned establishments and are omitted from Figure $4 b$.

In the employment column, the means of the number of workers are shown, with standard deviations in parentheses. The last column shows the share of imported intermediate inputs, with standard deviations in parentheses. 